\title{
MANAGING COMPANY'S FOREIGN CURRENCY LOAN TO INCREASE PERFORMANCE THROUGH ECONOMIC VALUE ADDED
}

\author{
Elizabeth Tiur Manurung \\ eliz@unpar.ac.id \\ Fakultas Ekonomi, Universitas Katolik Parahyangan \\ Jl. Ciumbuleuit 94, Bandung 40141
}

received: 13/9/18; revised: 18/9/18; published: 29/6/19

\begin{abstract}
One impact of global crisis, is increasing foreign currency rate of Indonesian IDR. Company with foreign debt exposures will suffer financial losses, if the exchange rate of the foreign currency becomes stronger. These losses will reduce the company Economic Value Added (EVA), and reduce the financial performance. Then, the purpose of this research is to calculate the effect of changes in foreign currency rates on the company's economic value added. Research method used in this study is Causal method. This study used company secondary data, based on Indonesian Stock Exchange. Based on research conducted, the result of this research proves that the changes in foreign currency rates on foreign liabilities affected significantly (with $\alpha=5 \%$ ) on company's economic value added. In PT. KF case, revenues earned by the company could cover all cost incurred including cost to cover the loss of exchange rate gap of foreign debt and capital cost.
\end{abstract}

Keywords: foreign currency rates; company's foreign debt; economic value added; foreign currency loss; company's performance

\section{INTRODUCTION}

The impact of technological progress gave very positive effect in the business world. Transactions can be done easily between buyers and sellers, or between producer - distributors - and consumers (Marshall, 2012). On the contrary, there is other impact on business. It is the competition in business increasingly sharp both domestically and overseas; this fact encouraged companies to increase their efficiency. Increasing volume of foreign transactions will also increase macroeconomic growth (Kompas, 02.03.17: 17).

Kurniasari's research (2017) concluded that one factor that can be influenced economic growth is foreign loan. Increasingly in economic growth could be increased productivity of the company and created value added and welfare of the society in general.

Generally, foreign trade transactions affected the situation of foreign economic. One of the influencing factor is global economic crisis, which has caused the fall of purchasing power of IDR in Indonesia currency; this happens because of the soaring exchange rate against US \$. As Ricardo (2014) quoted that unexpected currency fluctuation impact on future company's cash flow and can greatly affect the company's competitive position. US \$ currency is an international currency, which is often used internationally. It is because US
$\$$ is considered relatively stable in the economy. For the company which is has foreign debt, the fluctuation of foreign currency rate will make them suffering of financial loss and decrease their performance.

In this research, company's performance is in proxy through EVA. Triyono's research (2008) stated that government should do something so that the exchange rate can be kept under control with the support of increased in export and minimized import. The effect of changes in foreign company's debt on company's value is concluded to be very significant, just like Orientati's research (2014).

This research is different from previous research, for example, Suripto (2011) has already done a research on the influence of Capital structure on Value-based management (EVA), with a conclusion of positive and significant effect. It is also different from Kurniasari's research (2017) which stated that the examination of the impact of debt on macroeconomic growth. It is also different from Orientati's research (2014), about manufacturing sector. The article about Determining Economic value from Standford University (2018) also had a different result, stating that fluctuating in domestic market will expressed in domestic currency and will impact on incremental company's Net income. It's very clear that fluctuating in foreign currency will impact on company's profit significantly, as the result 
of Mamun's and Mansor's (2012) research. Therefore, the motivation on this research focuses on testing and analysis of the effect of foreign debt on EVA, which means that if debt is managed well, so it will not harm the company so that the company's performance can be improved.

Companies are always trying to improve their performance (William et. al, 2-15). To attract investors and creditors, performance that has been achieved by a company can be examined on their EVA Statement. If the EVA value is positive and increasing, then the company's performance will be better (Young and O'Byrne: 2001 in Suripto: 2011). Company needs more fund with the company's growing operations. To earn the fund, they need to earn it from either domestic or overseas financial institutions. Foreign exchange rate in foreign currency often fluctuates and company with debt exposure will suffer financial loss if the exchange rate of foreign currency becomes stronger. Based on this explanation, the objectives of this study are: (1) Calculating the impact of exchange rate fluctuating in foreign debt company, (2) Calculating company's performance based on EVA, (3) identifying the impact of exchange rate fluctuation on company performance.

Transactions that use foreign currencies are those transactions that buy or sell products or services with price denominated in foreign currencies (SAK: 2018). Transactions in foreign currencies are recorded using the exchange rate at the time of the transaction (spot rate). Accounting treatment at each Balance Sheet date, for monetary assets and liabilities in foreign currencies are reported in IDR at the exchange rate at the Balance Sheet date (Figure 1).

Inherent value determined by accounting standards, and if the exchange rate becomes stronger between transaction date and settlement date of foreign debt will be recognized immediately if it happens in one period. But if exchange rate fluctuated occurs in the next period then the recognition of gain or loss of exchange rate fluctuation is in several periods (SAK, 2018).

Foreign debt account will appear in Balance Sheet when the company does foreign sales or purchase transaction; or also when company makes foreign loan from foreign financial institutions. Exchange rate fluctuation will impact the value of foreign debt company's accounts, and company will suffer losses if IDR much weaker. Therefore, the foreign debt accounts must be managed properly to minimize company's financial loss. (Brigham et. al, 2013). Another research also quoted that Exchange rate fluctuation will impact company's performance through decreasing investor returns, therefore investors will release their shares (Daley, 2018). Similar with Daley (2018), Asogawa and Nkolika (2013) quoted that Real exchange rate and the degree of trade openness impact positively on the growth of investment.
Various procedures are formed by the company to reduce losses due to changes in exchange rate. One of the procedure, for example is hedging. Hedging protect currencies from foreign exchange exposure during the specified time period. As Weygand (2015) said, Hedging a particular currency exposure means establishing an offsetting currency position such that whatever is lost or gained on the original currency exposure is exactly offset by a corresponding foreign exchange gain or on the lost on the currency hedge.

EVA is a performance measurement based on economic value added by the company (Suripto, 2011). And according to Mariuki and Gatobu (2013) EVA is the incremental differences in the rate of return over the company's cost of capital. EVA value is obtained from the company's net income after tax and minus capital cost. EVA has been developed by Steward (2001 cited by Suripto: 2011) which was generally influenced by investment policy and funding policy/ Capital resources. Funding policy are often proxyed by the capital structure, which includes company's domestic or foreign debt. Therefore, changes in foreign currencies debt can directly affect the company's EVA or affect the company's performance.

Economic Value Added concept (Steward, 2001 in Suripto, 2011), is the measurement of the amount or profit remaining after counting for the return expected by the firm's investors. The steps in determining economic value added in general are: (1) Adjusting the balance sheet using capital employment concept to calculate invested capital; (2) Calculating cost of capital; (3) Calculating the capital charges; (4) Adjusting NOPAT based on EVA; (5) Calculating EVA.

According to Nelson (2015)'s opinion, EVA is calculated by: EVA = NOPAT - $($ WACC $x$ Capital Invested); where, NOPAT $=$ Net Operating Profit after Tax; Capital Invested $=$ Equity + Long term debt at the beginning capital; while $\mathrm{WACC}=\mathrm{ke} * \mathrm{E} /(\mathrm{E}+\mathrm{D})+$ $\mathrm{kd}(1-\mathrm{t}) * \mathrm{D} / \mathrm{ED}$. Where ke $=$ required return on Equity and $k d(1-t)=$ after tax return on Debt.

And according to Young \& O'Byrne (2001 cited by Suripto, 2011), to calculate EVA as shown in table 2 below, with the approach of comparing between conventional Statement of Financial position and Statement of Financial Position based on EVA.

The interpretation of EVA calculation result, such as if EVA value is positive, it means the company has been produced economic added value. And if EVA value is negative, it means company has not been produced economic added value, because the profit generated by the company could not cover all expenses including capital cost; so that negative EVA doesn't meet the expectations of all shareholders. If EVA value equals to zero, then from the economic point of view is a break event condition, where all revenues is used to recover all expenses included capital cost (Young and O’Byrne, 2001 cited by Suripto, 2011). 
The use of EVA is generally to achieve organizational goals, or to measure company's performance, to determine bonus for employees, to communicate company's performance with shareholder's and investors, to encourage manager's motivation, to determine capital budgeting, corporate valuation, and capital analysis (Young and O'Byrne, 2001 in Suripto, 2011). The main focus of EVA is to reevaluate company's performance through calculating company's added values: value creation. And with using EVA method, managers will try to act to create value for owners. Although EVA has very advantages, there are also some weaknesses of EVA, such as EVA only calculates one period of company's value creation. Therefore, if we add all value of EVA in several periods, the result may come up to negative value of EVA; and another weakness is that implementing EVA is not easy.

\section{METHODS}

The method used in this research is causal method, which is used to determine the causal relationship of the variables studied, for example changes in debt value due to changes in exchange rate, and their relationship with the performance of the company based on EVA.

For illustrative calculation, this study uses secondary data types obtained through Indonesian Stock Exchange official website. The secondary data mentioned before, refers to the financial statement of PT KF in 10 quarter periods. Besides, other data collection techniques used are using references from books and relevant previous researches. The variables studied are: (1) changes in exchange rate between transaction date and settlement date in this research refers to the changes of foreign debt in PT. KF; (2) EVA which measures the company's performance based on value creation.

Data analysis technique used in this study is linear regression, calculated by supporting software namely Statistical Package for Social Sciences V.23 (SPSS). The analysis and interpretation of data processed result will be compared to the right theory and to the relevant previous research result.

\section{RESULTS}

From the calculation of EVA of PT. KF from periods of 31 March 2004 - 30 June 2006, we found out that all value of EVA is positive. It means the revenues earned by the company could cover all costs incurred, including the cost to cover the loss of exchange rate gap of foreign debt, also cost of capital.

Table 3 showed that the different rate currency as entered variable and there is no removed variable, then the data has qualified enough to produce models.

\section{DISCUSSION}

The calculation result from Table 1 and 2 showed us that there is gain or loss affected by foreign currency changes in foreign debt. Although the company suffer financial losses from exchange rate changes, but the EVA still have positive value. This means the total income used to recover all operation expenses in company including loss of exchange rate fluctuation in June, September, and Desember (in Quater 2, 3, and 4), even revenues can still pay cost of capital, so company still can create increasing values to the shareholders.

Regression model resulted from the calculation is (Table 3):

$$
\mathrm{Y}=325,427,298,718-3.749 \mathrm{X}
$$

In which: $X=$ the different rate of foreign debt currency, and $\mathrm{Y}=$ Economic Value Added (EVA); Regression Coefficient value (b) is negative amount 3.749 indicates when exchange rate fluctuation occurs then foreign debt value will increase, on the contrary EVA value will decrease. So, it is very important for company to manage their foreign debt to prevent company from greater financial losses of foreign exchange rate in their foreign debt account. Correlation Coefficient $(r)=-0.690$; the value of negative 0.690 as correlation coefficient shows that foreign exchange rate and EVA move in different and contradictive way. Therefore, if exchange rate fluctuation has an impact to increase foreign debt value, EVA value will decrease. This indicates that company's performance has decrease too. Correlation coefficient value equals to negative 0.690 , which means the relation between variable EVA and foreign debt is fluctuating in the moderate level correlation.

Therefore the change in exchange rate in foreign loan post of the company significantly affects EVA. This was proved by significant value of $2.7 \%$ which means changes in foreign currency affected EVA significantly.

Significant value ( $\rho$ value) of $2.77 \%$ is smaller than $\alpha=10 \%$. Therefore it means changes in foreign currency in company's debt has significant impact on EVA, which shows that $\rho$ value $=2.77 \%$ means the chance to make a mistake of $2,7 \%$ or in other words about $87.3 \%$ is believed that the correct conclusion has been drawn. This research result is not different with Kurniasari's (2017) research that quotes that foreign debt significantly impact the economic value growth.

Determinant coefficient (R Square) in this case is $47.7 \%$, which means $47.7 \%$ of the company's EVA can be explained by the difference of the exchange rate of foreign loan post variable. Other factors that affect a company's EVA is the company's operation itself and the company's management performance because the value of EVA is calculated by deducting the capital cost from its Net Operating Profit after tax (NOPAT). As long as 
the company's management is done, their operation with efficiently and effectively (so the company's NOPAT is high and can cover the company's capital cost), the value of EVA will always be positive and increase, and will also increase company's performance. This result is not different with Orientati's (2014) who stated that company's debt has significant impact on company's value. Also similar to the result research of Duma (2016) who quoted that the fluctuating in exchange rate of the US Dollar and the Euro tended to lead to change the company's performance.

Due to how significant the effect of company's foreign debt on EVA, especially when there are currency rate changes, the company has to manage their foreign debt seriously. Company has to invest their foreign debt to their productive operations/ investment, and make better return for paying their interest expenses, pay cost of capital and also make recovery from company financial suffering when there is loss from exchange rate fluctuation. Hedging also recommended, because Hedging protects the currency from foreign exchange rate exposure.

\section{CONCLUSIONS}

From what has been researched, it can be concluded that, the company gets most of its foreign fund from banks, which are The Royal Bank of Scotland plc., Singapore; and loan facility that was obtained from subsidiary of Citibank, N.A., Jakarta, PT Indosuez Indonesia Bank, PT Bank Lippo Tbk., and Commonwealth Bank, Jakarta. The changes in exchange rate in foreign debt of the company significantly affects EVA. This was proved by significant value of 0.027 , and has moderate relation. And due to how significant the effect of company's foreign debt on EVA, the company has to manage their foreign debt seriously. Company has to invest their foreign debt to their productive operations/ investment, and make better return for paying their interest expenses, paying cost of capital and also make recovery from company financial suffering when there is loss from exchange rate fluctuation. Hedging is also recommended, because Hedging protects the currency from foreign exchange rate exposure.

\section{REFERENCES}

Asogawa, Fredrick Onyebuchi; \& Okeke Mercy Nkolika. 2013. Value Added Tax and Investment Growth in Nigeria: Time series Analysis. IOSR Jounal of Humanities and Social Science (IOSRJHSS). December 2013.

Brigham Eugene F., and Phillip R. Daves. 2013. 11th Edition. Intermediate Financial Management. US: South-Western Publisher.

Daley, Michael. 2018. Currency Exchange Rate
Fluctuation and Their impact on Portofolio Returns. Bnymelionwealth.com. July 2018.

Duma, Johnmark Obura. 2016. Effect of Foreign Exchange Rates Fluctuation on Performance of Nairobi Securities Exchange Market. International Journal of Business and Management Invention. Vol 5 Issue 10; October 2016.

Ikatan Akuntan Indonesia: Dewan Akuntansi Indonesia 2018. Standar Akuntansi Keuangan. Jakarta: Penerbit Salemba Empat.

Kurniasari, Dwi. 2017. Pengaruh Hutang Luar Negeri, Penanaman Modal Asing, Penanaman Modal Dalam Negeri, dan Tenaga kerja terhadap Pertumbuhan Ekonomi Indonesia.Skripsi Fakultas Ekonomi \& Bisnis Universitas Lampung.

Mamun, Abdulah Al and Shazali Abu Mansor. 2012. Economic Value Added as Superior Performance Measurement Tool. Journal Modern Economy. Vol 3 No 3; 2012, 310-318.

Mariuki and Timothy Gatobu. 2013. The Effect of Foreign exchange rate Fluctuations on The Financial Performance of Listed Companies in Kenya. Erepository.uonbi.ac.ke.

Marshall B. Romney, \& Paul J. Steeinbart. 2012. Accounting Information Systems. United States: Pearson Publisher.

Orientati, Suci. 2014. Pengaruh Hutang terhadap Nilai Perusahaan, dengan Ukuran Perusahaan sebagai variabel Moderasi (Studi pada perusahaan Manufaktur yang terdaftar di BEI periode 20112013). Skripsi Fakultas Ekonomi Negeri Jogya. 2014.

Ricardo, Elvis. 2014. Article: Exchange Rate Risk: Economic exposure. Investopedia.com/articles/ forex/021114/exchange-rate-risk-economicexposure.asp

Standford University, article. 2018. Determining Economic Value. www.web/standford edu/group/ FRI/Indonesia/documents/gittinger.

Suripto.2011. Model Penciptaan Nilai Tambah Ekonomis dan Nilai Perusahaan.Publikasi pada Jurnal Keuangan dan Perbankan Vol. 15 No. 2, September 2011; Terakreditasi SK No. 64a/DIKTI/ Kep/2010; pp. 392-404.

Triyono.2008. Analisis Perubahan Kurs Rupiah terhadap Dollar Amerika.Publikasi pada Jurnal Ekonomi Pembangunan Vol 9 No. 2.Desember 2008. pp. 156-167

Weygandt, Jerry J., Donald E. Kieso., and Terry D. Warfield. 2015. 3rd edition.FinancialAccounting - IFRS Version.US: John Wiley and Sons, Inc. Publisher.

Williams Jan R., Susan F. Haka, Mark S. Bettner, Joseph V. Carcello. 2015. 17th Edition.Managerial Accounting: The Basis for Business Decisions. US: McGraw-Hill Publisher. 
Tabel 1. EVA PT K F Tbk.

\begin{tabular}{ccccc}
\hline Year & 31 Mart & 30 June & 30 September & 31 Desember \\
\hline 04:NOPAT & IDR148,569,484,163 & IDR252,051,993,157 & IDR417,505,114,796 & IDR612,055,310,412 \\
- cost of capital & IDR 46,338,785,608 & IDR101,177,168,195 & IDR160,431,686,468 & IDR181,355,233,668 \\
EVA & IDR102,230,698,555 & IDR150,874,824,962 & IDR257,073,428,328 & IDR430,700,076,744 \\
05:NOPAT & IDR314,270,809,903 & IDR398,533,443,154 & IDR644,920,558,916 & IDR830,992,205,384 \\
- Cost of capital & IDR 61,003,221,123 & IDR117,576,008,856 & IDR203,170,683,175 & IDR242,985,133,441 \\
EVA & IDR 253,267,588,780 & IDR 280,957,434,298 & IDR 441,749,875,741 & IDR 588,007,071,943 \\
2006: NOPAT & IDR 207,075,681,694 & IDR 469,788,579,536 & & \\
- cost of capital & IDR 56,423,249,794 & IDR 122,522,793,056 & & \\
EVA & IDR 150,652,431,900 & IDR 347,265,786,480 & & \\
\hline
\end{tabular}

Source: Thanks to Sylvina Y. for sharing the data.

Tabel 2. Exchange rate changes in Foreign Debt and EVA at Year End In Period of 31 Maret 2004 - 30 Juni 2006

\begin{tabular}{lrc}
\hline \multicolumn{1}{c}{ Period } & $\begin{array}{c}\text { Gain (Loss) of } \\
\text { exchange rate } \\
\text { changes }\end{array}$ & EVA \\
\hline 31 March 2004 & $48,012,521,390$ & $102,230,698,555$ \\
30 June 2004 & $7,400,903,361$ & $150,874,824,962$ \\
30 September 2004 & $20,351,665,024$ & $257,073,428,328$ \\
31 Desember 2004 & $11,508,562,049$ & $430,700,076,744$ \\
31 March 2005 & $6,868,327,579$ & $253,267,588,780$ \\
30 June 2005 & $(9,836,653,216)$ & $280,957,434,298$ \\
30 September 2005 & $(52,541,921,948)$ & $441,749,875,741$ \\
31 Desember 2005 & $(16,233,644,578)$ & $588,007,071,943$ \\
31 March 2006 & $35,342,086,032$ & $150,652,431,900$ \\
30 June 2006 & $16,207,401,955$ & $347,265,786,480$ \\
\hline
\end{tabular}

Source: calculating process.

Table 3. Coefficients(a)

\begin{tabular}{|c|c|c|c|c|c|c|}
\hline & & \multicolumn{2}{|c|}{$\begin{array}{c}\text { Unstandardized } \\
\text { Coefficients }\end{array}$} & $\begin{array}{l}\text { Standardized } \\
\text { Coefficients }\end{array}$ & \multirow[b]{2}{*}{$\mathrm{t}$} & \multirow[b]{2}{*}{ Sig. } \\
\hline \multicolumn{2}{|c|}{ Model } & B & $\begin{array}{l}\mathrm{Std} . \\
\text { Error }\end{array}$ & Beta & & \\
\hline \multirow[t]{4}{*}{1} & (Constant) & 325427 & 38247 & & 8.509 & .000 \\
\hline & & 298718 & 276623 & & & \\
\hline & & .710 & .230 & & & \\
\hline & $\begin{array}{l}\text { Different } \\
\text { rate }\end{array}$ & -3.749 & 1.389 & -.690 & -2.700 & .027 \\
\hline
\end{tabular}

a. Dependent Variable: EVA

\begin{tabular}{|c|c|c|c|}
\hline & Liabilities\& & & Invested \\
\hline Total Assets & Equities & Net Asset & Capital \\
\hline Cash & \multirow[t]{2}{*}{$\begin{array}{c}\text { Current } \\
\text { Liabilities }\end{array}$} & \multirow{3}{*}{ Cash } & \multirow{4}{*}{$\begin{array}{c}\text { Current } \\
\text { Liabilities }\end{array}$} \\
\hline $\begin{array}{c}\text { Accounts } \\
\text { Receivable }\end{array}$ & & & \\
\hline $\begin{array}{c}+ \\
\text { Inventories }\end{array}$ & \multirow[t]{2}{*}{$\begin{array}{c}\text { Short term } \\
\text { NIBL }\end{array}$} & & \\
\hline+ & & \multirow[b]{2}{*}{ WCR } & \\
\hline $\begin{array}{l}\text { Prepaid } \\
\text { Expense }\end{array}$ & $\begin{array}{l}\text { Long term } \\
\text { Liabilities }\end{array}$ & & $\begin{array}{l}\text { Long term } \\
\text { Liabilities }\end{array}$ \\
\hline \multirow{3}{*}{ Fixed Assets } & $\begin{array}{c}\text { Other } \\
\text { Long term } \\
\text { liabilities }\end{array}$ & \multirow{3}{*}{$\begin{array}{l}\text { Fixed } \\
\text { Assets }\end{array}$} & $\begin{array}{c}\text { Other Long } \\
\text { term liabilities }\end{array}$ \\
\hline & & & \\
\hline & $\begin{array}{c}\text { Stockholders } \\
\text { Equity }\end{array}$ & & $\begin{array}{c}\text { Stockholders } \\
\text { Equity }\end{array}$ \\
\hline
\end{tabular}

Traditional Statement of

Statement of Financial Position

Notes:

WCR $=$ Working Capital Requirement;

$\mathrm{WCR}=($ Inventory + Accounts Receivable + other current assets + operating cash $)-($ Liabilities + due date expense + advanced receive/revenue);

NIBL $=$ Non-Interest Bearing Liabilities

Source: S. David Young and Stephen O'Byrne (2001 cited by Suripto: 2011)

Figure 1. The Comparison of Traditional Statement of Financial Position and EVA-Statement of Financial Position 